\title{
Minerals Composition of Marine Macro Algae Collected from Olaikuda, Rameshwaram, Gulf of Mannar, Southeast Coast of India
}

\author{
Suparna Roy ${ }^{1}$, P. Anantharaman ${ }^{2}$ \\ C. A. S. in Marine Biology, Faculty of Marine Sciences, Annamalai University, Tamil Nadu, India ${ }^{1,2}$
}

\begin{abstract}
Minerals are essential for human body to regulate the metabolic processes but some elements are also toxic to human body. Seaweeds are taken as food items in different developed and developing countries. So, estimation of minerals composition of seaweeds including the trace metals is important to evaluate food safety. On the other hand, the industrial effluents with pollutant, including toxic heavy metals have adverse effects on the aquatic environment. Different costly conventional treatment technologies are applying for removal of heavy metals from the marine environment. These techniques are economically less beneficial and produce a huge load of toxic chemical sludge on the environment. So, remediation of heavy metals by marine macro algae is a novel eco-friendly alternative approach. The Inductively Coupled Plasma-Optical Emission Spectroscopy (ICP-OES) has been applied to analyse elements such as ( $\mathrm{Ag}, \mathrm{Cu}, \mathrm{Co}, \mathrm{Ni}, \mathrm{Mn}, \mathrm{Cr}, \mathrm{Pb}, \mathrm{Zn}, \mathrm{Cd}, \mathrm{Al}, \mathrm{B}, \mathrm{Fe}, \mathrm{Mg}$ and $\mathrm{Na}$ ) of some seaweeds. The two separate standard methods of acid digestion were used to estimate the minerals composition. The aim of study is to evaluate the composition of minerals including heavy metal. From this study, it is concluded that in compare to other seaweeds species, heavy metals are present in high amount in Valoniopsis pachynema, so this species may be used as heavy metals remediator and is not safe to consider as edible. Accordingly, Codium tomentosum and Gracilaria opuntia contain high amount of aluminium, sodium and boron, so these species should also not be consider as edible.
\end{abstract}

Keywords: Seaweeds; elemental composition; heavy metals; Phycoremediation; Olaikuda.

\section{INTRODUCTION}

The anthropogenic activities such as chemical disposal from industries, effluents from nuclear power plant, metal mining, metal processing activities and the discharges from different industries gradually contaminating the marine environments. As a result, removal of toxic heavy metals from environment has become a priority. Heavy metals are gradually accumulating in the environment and food chain, as they are non-degradable, so create a potential risk to the environment and indirectly to human health. Some of them are carcinogenic, mutagenic, and causes potential risk for developing major diseases (Ali et al. 2013). The conventional technologies are cost-effective treatment in comparing to phyco-remediation which appears feasible and economically attractive approach (Storelli et al. 2001). Few heavy metals have adequate chemical and toxic effect on the environment.

Specifically, $\mathrm{As}, \mathrm{Hg}, \mathrm{Pb}, \mathrm{Cd}, \mathrm{Cr}, \mathrm{Cu}$ are generally toxic even at very low concentration and they have indispensable essential properties with different threshold levels in different types of plants and organisms including human. Marine macro algae accumulate trace metals at thousands of times higher than the corresponding concentrations in seawater. It accumulates only free metal ions depending on the dissolved organic and inorganic materials. They play an important role in the nutrient dynamics of marine ecosystems and reflect any changes in water quality efficiently (Wilson et al. 2002).

Heavy metals are well-known for their persistence in the environment and their ability of bioaccumulation and biomagnifications in the food chain which causes irreparable damage to the marine environment (Gochfeld, 2003). The cell wall of seaweeds composed of polysaccharides and proteins with anionic carboxyl, sulphate and phosphate groups which are excellent binding sites for metals. This makes algal biomass one of the most promising bio-borbents for removal of toxic heavy metals from industrial waste waters (Volesky et al. 1999). Consequently, seaweeds contain a high amount of necessary macro minerals also (Bocanegra et al. 2003). Aquatic organisms have been used as bioindicators to assess the heavy metals pollution. Macro and micro algae, molluscs are most used for this purpose (Villares et al. 2002; Lavoie-Michel et al. 2009; Rajfur et al. 2010). Seaweeds consumption has been increasing in western countries in recent years because of its nutritive benefits (Dawczynski et al. 2007). Seaweeds offer a bioavailable, alternative dietary source of macro, trace, and ultra-trace elements (Bocanegra et al. 2003; Romarís-Hortas et al. 2011). Therefore, seaweeds as functional ingredient are attracting much attention (Gupta et al. 2011). The estimation of mineral composition of seaweed is important for nutritional and the toxicological aspects. 


\section{UGC Approved Journal}

\section{MATERIALS AND METHODS}

A brief description of sampling station: The area of Rameshwaram is 51.8 sq. Kms. ( $09^{\circ} 18.390^{\prime}$ ' $\mathrm{N} 079^{\circ} 20.076^{\prime}$ 'E) and a small island and major pilgrim centre in the Gulf of Mannar, Tamilnadu, India. It is connected to the mainland by Pamban Bridge. Olaikuda beach $\left(09^{\circ} 18.853^{\prime} \mathrm{N} 079^{\circ} 20.141^{\prime} \mathrm{E}\right)$ is one kilometre away from the principal shrine of Rameshwaram. It is surrounded by seaweeds and coral reefs.

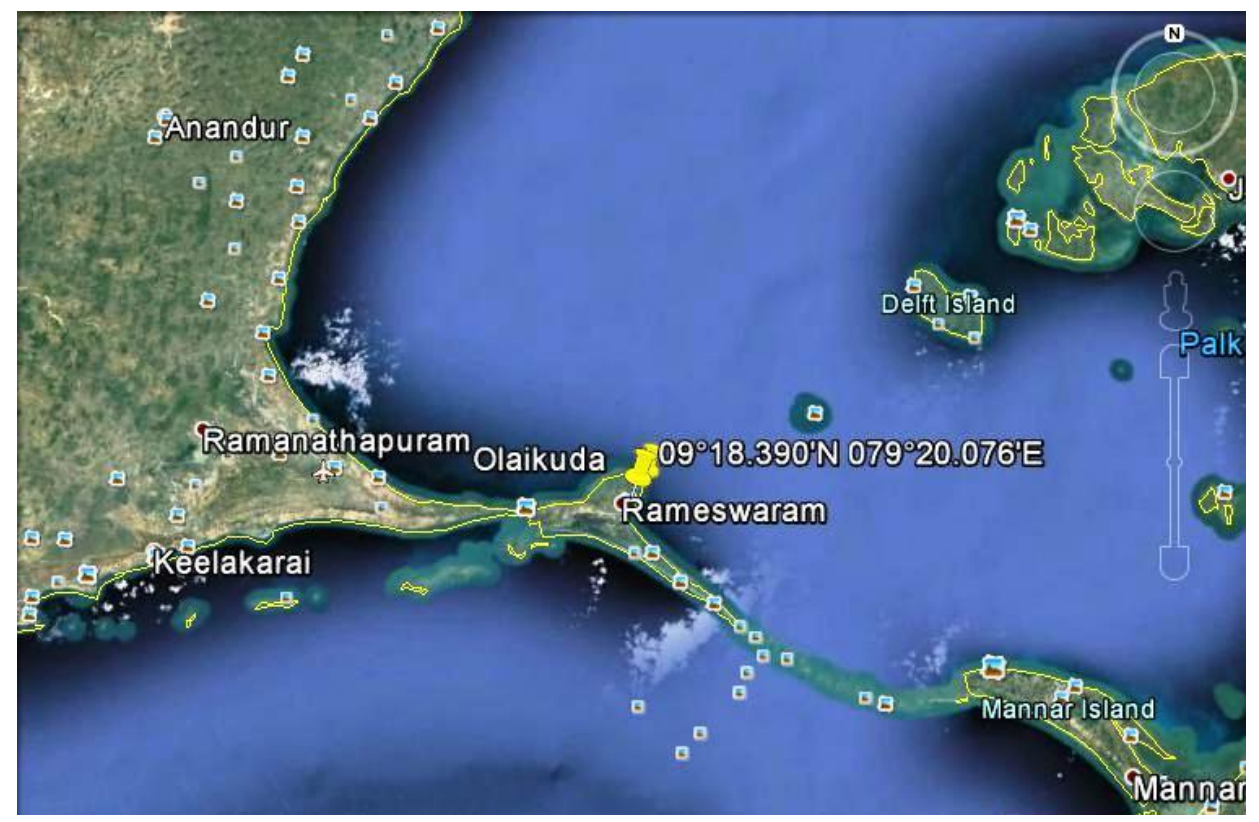

Map showed sampling location (map generated from goggle earth).

b. Analytical methods of sample preparation: Seaweeds such as Chlorophyta Codium tomentosum Stackhouse, Halimeda gracilis Harvey ex J Agardh, Valoniopsis pachynema (Martens) Boergesen, Caulerpa racemosa var. macrophysa (Sonder ex Kutzing) W. R. Taylor; Phaeophyta Hydroclathrus clathratus (C Agardh) Howe and Rhodophyta Acanthophora spicifera (Vahl) Boergesen and Gracilaria opuntia Durairatnam. Nom Inval was collected from Olaikuda, Rameshwaram during Pre monsoon period (April' 2016). Seaweeds were repeatedly washed with sterilized and filtered in-situ seawater to remove sand, soil and the attached epiphytes and shade dried for one week. Dried seaweeds were grinded to make powder. Two method of acid digestions were applied to estimation the mineral compositions.

Acid digestion method 1: Each powder samples about $1 \mathrm{gm}$ of dry weight were used for acid digestion. The samples were taken in a $250 \mathrm{ml}$ conical flask and $8 \mathrm{ml}$ of concentrated $10 \% \mathrm{HNO} 3$ was added to each sample and kept the samples at room temperature $\left(28^{\circ} \mathrm{C}-34^{\circ} \mathrm{C}\right)$ for 18 hours; filtered the samples with What man (589/2) filter paper and the filtrate was collected in a $250 \mathrm{ml}$ clean conical flask and diluted accurately to $25 \mathrm{ml}$ with the distilled water and the samples were analysed at Inductively Coupled Plasma-Optical Emission Spectroscopy (ICP-OES).

Acid digestion method 2: The seaweeds powder had been taken in the conical flask and $20 \mathrm{ml}$ concentrated $\mathrm{HNO}_{3}$ was added to it. The mixtures were kept at room temperature $\left(28-34^{\circ} \mathrm{C}\right)$ for $28 \mathrm{hrs}$. Then samples were boiled at $120^{\mathrm{C}} \mathrm{C}$ hotplates and evaporated to dryness. The dry samples in the conical flask were left at room temperature for 18 hours; then added $20 \mathrm{ml}$ of Nitric acid and Perchloric acid (4:1) to each sample, acidified samples were again boiled and evaporated to dryness at $120 \mathrm{C}$ hotplates. The samples were cool for few hours and the $20 \mathrm{ml} 10 \%$ concentrated $\mathrm{HNO}_{3}$ were added to it and filtered the samples with What man (589/2) filter paper covering cotton and the filtrates were collected in a $250 \mathrm{ml}$ clean conical flasks and diluted accurately to $25 \mathrm{ml}$ volume with distilled water and the samples were analysed with Inductively Coupled Plasma-Optical Emission Spectroscopy (ICP-OES).

c. Statistical Analysis: The triplicate of each sample were analysed and expressed as mean \pm standard deviation.

Results: The estimated minerals including heavy metals by two acid digestions have been summarized separately in table 1. The relative abundance of the bio-essential elements in studied species are as follows $\mathrm{Na}>\mathrm{Mg}>\mathrm{Fe}>\mathrm{Al}>\mathrm{B}>\mathrm{Mn}>\mathrm{Zn}>\mathrm{Cu}>\mathrm{Co}$. Nonessential or heavy metals showed no such type of general trend. The minerals such as $\mathrm{Ag}, \mathrm{Ni}, \mathrm{Cr}$ and $\mathrm{Pb}$ are present as high amount in Valoniopsis pachynema followed by Halimeda gracilis and Gracilaria opuntia. Caulerpa racemosa var. macrophysa contain maximum Na (1156.68 $\pm 0.65 \mu \mathrm{g} / \mathrm{gm})$; Codium 


\section{UGC Approved Journal}

tomentosum has $\mathrm{Mg}(336.71 \pm 0.45 \mu \mathrm{g} / \mathrm{gm})$ and $\mathrm{Al}(385.06 \pm 0.58 \mu \mathrm{g} / \mathrm{gm})$; Valoniopsis pachynema has $\mathrm{Fe}(72.7 \pm 0.26$ $\mu \mathrm{g} / \mathrm{gm})$ and $\mathrm{Cu}(0.26 \pm 0.06 \mu \mathrm{g} / \mathrm{gm})$ likewise Gracilaria opuntia contain B $(5.13 \pm 0.01 \mu \mathrm{g} / \mathrm{gm})$, Co $(0.13 \pm 0.01 \mu \mathrm{g} / \mathrm{gm})$ and $\mathrm{Zn}(0.65 \pm 0.01 \mu \mathrm{g} / \mathrm{gm})$. The mineral compositions of seaweeds by two different types of acid digestion had been revealed that the accuracy of estimation of minerals is depended on types of acid used and time duration of acid digestion. The acid digestion method 2 is preferable for mineral estimation, as it is estimated minerals in better quantity.

Table 1: Minerals composition of seaweeds

\begin{tabular}{|c|c|c|c|c|c|c|c|}
\hline \multicolumn{8}{|c|}{$\begin{array}{l}\text { Acid digestion method 1: The element content }(\mu \mathrm{g} / \mathrm{gm}) \text { in dry weight } \\
\text { Caulerpa racemosa var. macrophysa= Caulerpa racemosa. } \mathrm{M}\end{array}$} \\
\hline $\begin{array}{l}\text { Species } \\
\text { Elements }\end{array}$ & $\begin{array}{l}\text { Acanthophora } \\
\text { spicifera }\end{array}$ & $\begin{array}{l}\text { Codium } \\
\text { tomentosum }\end{array}$ & $\begin{array}{l}\text { Halimeda } \\
\text { gracilis }\end{array}$ & $\begin{array}{l}\text { Gracilaria } \\
\text { opuntia }\end{array}$ & $\begin{array}{l}\text { Valoniopsis } \\
\text { pachynema }\end{array}$ & $\begin{array}{l}\text { Caulerpa } \\
\text { racemosa.m }\end{array}$ & $\begin{array}{l}\text { Hydroclathrus } \\
\text { clathratus }\end{array}$ \\
\hline $\mathrm{Ag}$ & $0.10 \pm 0.005$ & $0.02 \pm 0.005$ & $0.11 \pm 0.00$ & $0.12 \pm 0.02$ & $0.12 \pm 0.004$ & $0.12 \pm 0.00$ & $0.23 \pm 0.05$ \\
\hline $\mathrm{Cu}$ & $0.12 \pm 0.01$ & $0.01 \pm 0.00$ & $0.10 \pm 0.01$ & $0.02 \pm 0.01$ & $0.20 \pm 0.00$ & $0.13 \pm 0.01$ & $0.12 \pm 0.01$ \\
\hline Co & $0.01 \pm 0.01$ & \begin{tabular}{|l|}
$0.01 \pm 0.00$ \\
\end{tabular} & $0.01 \pm 0.00$ & \begin{tabular}{|c|c|}
$\mathbf{0 . 1 0} \pm 0.00$ \\
\end{tabular} & $0.03 \pm 0.01$ & $0.01 \pm 0.00$ & $0.01 \pm 0.00$ \\
\hline $\mathrm{Ni}$ & $0.04 \pm 0.05$ & $0.1 \pm 0.00$ & $0.02 \pm 0.00$ & $0.04 \pm 0.01$ & $\mathbf{0 . 1 1} \pm 0.01$ & $0.1 \pm 0.00$ & $0.1 \pm 0.00$ \\
\hline $\mathrm{Mn}$ & $0.96 \pm 0.05$ & $1 \pm 0.00$ & $1.14 \pm 0.05$ & $2.3 \pm 0.20$ & $7.9 \pm 0.66$ & $1.23 \pm 0.05$ & $1.24 \pm 0.01$ \\
\hline $\mathrm{Cr}$ & $0.01 \pm 0.00$ & $0.10 \pm 0.00$ & $0.11 \pm 0.00$ & $0.01 \pm 0.00$ & $0.20 \pm 0.00$ & $0.02 \pm 0.00$ & $0.04 \pm 0.02$ \\
\hline $\mathrm{Pb}$ & $0.13 \pm 0.05$ & $0.03 \pm 0.01$ & $0.12 \pm 0.00$ & $0.03 \pm 0.01$ & $0.12 \pm 0.00$ & $0.04 \pm 0.01$ & $0.10 \pm 0.00$ \\
\hline $\mathrm{Zn}$ & $0.23 \pm 0.02$ & $0.2 \pm 0.05$ & $0.21 \pm 0.00$ & 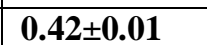 & $0.32 \pm 0.01$ & $0.19 \pm 0.01$ & $0.19 \pm 0.01$ \\
\hline $\mathrm{Cd}$ & $0.02 \pm 0.01$ & \begin{tabular}{|l|}
$0.01 \pm 0.00$ \\
\end{tabular} & $0.01 \pm 0.00$ & $0.01 \pm 0.00$ & $0.01 \pm 0.00$ & $0.01 \pm 0.00$ & $0.02 \pm 0.00$ \\
\hline $\mathrm{Al}$ & $49.79 \pm 0.56$ & $381.35 \pm 1.14$ & $22.10 \pm 0.92$ & $182.31 \pm 0.46$ & $191.16 \pm 0.98$ & $271.54 \pm 1.00$ & $271.54 \pm 1.00$ \\
\hline B & $4.23 \pm 0.69$ & $1.32 \pm 0.12$ & $1.02 \pm 0.06$ & $5.45 \pm 0.57$ & $3.12 \pm 0.01$ & $1.19 \pm 0.11$ & $1.99 \pm 0.01$ \\
\hline $\mathrm{Fe}$ & $7.29 \pm 0.80$ & \begin{tabular}{|l|l}
$27.14 \pm 0.96$ \\
\end{tabular} & $7.71 \pm 0.61$ & $6.05 \pm 0.89$ & $70.11 \pm 0.01$ & \begin{tabular}{|l|l}
$10.06 \pm 0.12$ \\
\end{tabular} & \begin{tabular}{|l}
$19.99 \pm 0.01$ \\
\end{tabular} \\
\hline $\mathrm{Mg}$ & $158.69 \pm 0.49$ & $333.12 \pm 0.94$ & $50.41 \pm 0.52$ & $53.14 \pm 1.02$ & $157.11 \pm 0.99$ & $94.41 \pm 2.45$ & $108.48 \pm 1.51$ \\
\hline $\mathrm{Na}$ & $387.08 \pm 2.05$ & $1000.09 \pm 1.06$ & $245.78 \pm 0.38$ & $201.19 \pm 1.17$ & $661.10 \pm 1.00$ & $1089.05 \pm 18.17$ & $242.04 \pm 1.05$ \\
\hline \multicolumn{8}{|c|}{ Acid digestion method 2: The element content $(\mu \mathrm{g} / \mathrm{gm})$ in dry weight } \\
\hline $\mathrm{Ag}$ & $0.11 \pm 0.06$ & $0.05 \pm 0.03$ & $0.12 \pm 0.06$ & $0.15 \pm 0.12$ & 0.35 & $0.21 \pm 0.17$ & \begin{tabular}{|l}
$0.04 \pm 0.01$ \\
\end{tabular} \\
\hline $\mathrm{Cu}$ & $0.18 \pm 0.06$ & $0.06 \pm 0.04$ & $0.12 \pm 0.07$ & $0.06 \pm 0.02$ & $0.26 \pm 0.06$ & $0.17 \pm 0.15$ & $0.18 \pm 0.06$ \\
\hline Co & $0.02 \pm 0.01$ & $0.01 \pm 0.00$ & $0.01 \pm 0.00$ & $\mid 0.13 \pm 0.01$ & $0.05 \pm 0.00$ & $0.01 \pm 0.00$ & $0.01 \pm 0.00$ \\
\hline $\mathrm{Ni}$ & $0.12 \pm 0.00$ & $0.12 \pm 0.00$ & $0.07 \pm 0.00$ & $0.08 \pm 0.01$ & $0.22 \pm 0.01$ & $0.15 \pm 0.01$ & $0.12 \pm 0.01$ \\
\hline $\mathrm{Mn}$ & $1.86 \pm 0.01$ & $1.91 \pm 0.03$ & $1.26 \pm 0.01$ & \begin{tabular}{|l}
$2.88 \pm 0.02$ \\
\end{tabular} & $8.27 \pm 0.06$ & $1.33 \pm 0.01$ & $1.27 \pm 0.05$ \\
\hline $\mathrm{Cr}$ & $0.06 \pm 0.01$ & $0.11 \pm 0.00$ & $0.13 \pm 0.01$ & $0.05 \pm 0.01$ & $0.25 \pm 0.00$ & $0.08 \pm 0.01$ & $0.08 \pm 0.00$ \\
\hline $\mathrm{Pb}$ & $0.05 \pm 0.00$ & $0.08 \pm 0.00$ & $0.15 \pm 0.01$ & $0.07 \pm 0.00$ & $0.17 \pm 0.01$ & $0.08 \pm 0.00$ & $0.11 \pm 0.02$ \\
\hline $\mathrm{Zn}$ & $0.45 \pm 0.03$ & $0.45 \pm 0.00$ & $0.45 \pm 0.00$ & 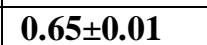 & $0.64 \pm 0.01$ & $0.24 \pm 0.01$ & $0.27 \pm 0.01$ \\
\hline $\mathrm{Fe}$ & $10.91 \pm 0.07$ & $30.7 \pm 0.48$ & $9.89 \pm 0.09$ & $7.85 \pm 0.12$ & $72.7 \pm 0.26$ & $11.16 \pm 0.02$ & $22.26 \pm 0.05$ \\
\hline $\mathrm{Mg}$ & $160.98 \pm 0.19$ & $336.71 \pm 0.45$ & $52.64 \pm 0.63$ & $57.28 \pm 0.80$ & $159.60 \pm 0.39$ & \begin{tabular}{|c|}
$99.86 \pm 0.12$ \\
\end{tabular} & $115.72 \pm 0.19$ \\
\hline $\mathrm{Na}$ & $404.26 \pm 1.10$ & \begin{tabular}{|c|c|}
$1046 \pm 0.28$ \\
\end{tabular} & $257.37 \pm 0.44$ & $209.72 \pm 0.23$ & $669.05 \pm 0.20$ & \begin{tabular}{|l|}
$1156.68 \pm 0.65$ \\
\end{tabular} & $244.50 \pm 0.43$ \\
\hline $\mathrm{Al}$ & $52.7 \pm 0.43$ & $385.06 \pm 0.58$ & $24.26 \pm 0.26$ & $184.92 \pm 0.62$ & $194.58 \pm 0.75$ & $273 \pm 0.44$ & $18.72 \pm 0.24$ \\
\hline $\mathrm{B}$ & $3.58 \pm 0.01$ & $0.94 \pm 0.01$ & $0.63 \pm 0.01$ & $5.13 \pm 0.01$ & $2.61 \pm 0.01$ & $0.78 \pm 0.01$ & $1.15 \pm 0.01$ \\
\hline $\mathrm{Cd}$ & $0.05 \pm 0.00$ & $0.02 \pm 0.01$ & $0.01 \pm 0.00$ & $0.01 \pm 0.00$ & $0.01 \pm 0.00$ & $0.02 \pm 0.00$ & $0.01 \pm 0.00$ \\
\hline
\end{tabular}

Table 2 Elements measured in ICP-OES to the mentioned Wave lengths (nm).

\begin{tabular}{|c|c|c|c|c|}
\hline Metal & \multicolumn{2}{|c|}{ Wavelengths } & Metal & Wavelengths \\
\hline $\mathrm{Ag}$ & 243.779 & 338.289 & B & 249.772 \\
\hline $\mathrm{Al}$ & 167.019 & 396.152 & $\mathrm{Cr}$ & 267.716 \\
\hline $\mathrm{Cd}$ & 226.502 & 228.802 & $\mathrm{Fe}$ & 238.204 \\
\hline $\mathrm{Cu}$ & 213.598 & 324.754 & $\mathrm{Mg}$ & 285.213 \\
\hline $\mathrm{Mn}$ & 257.610 & 259.372 & $\mathrm{Ni}$ & 231.604 \\
\hline Co & 238.892 & 237.863 & $\mathrm{~Pb}$ & 220.365 \\
\hline $\mathrm{Na}$ & 330.237 & 589.592 & $\mathrm{Zn}$ & 213.857 \\
\hline
\end{tabular}


UGC Approved Journal

Graphs represent the result of pre-treatment-I.
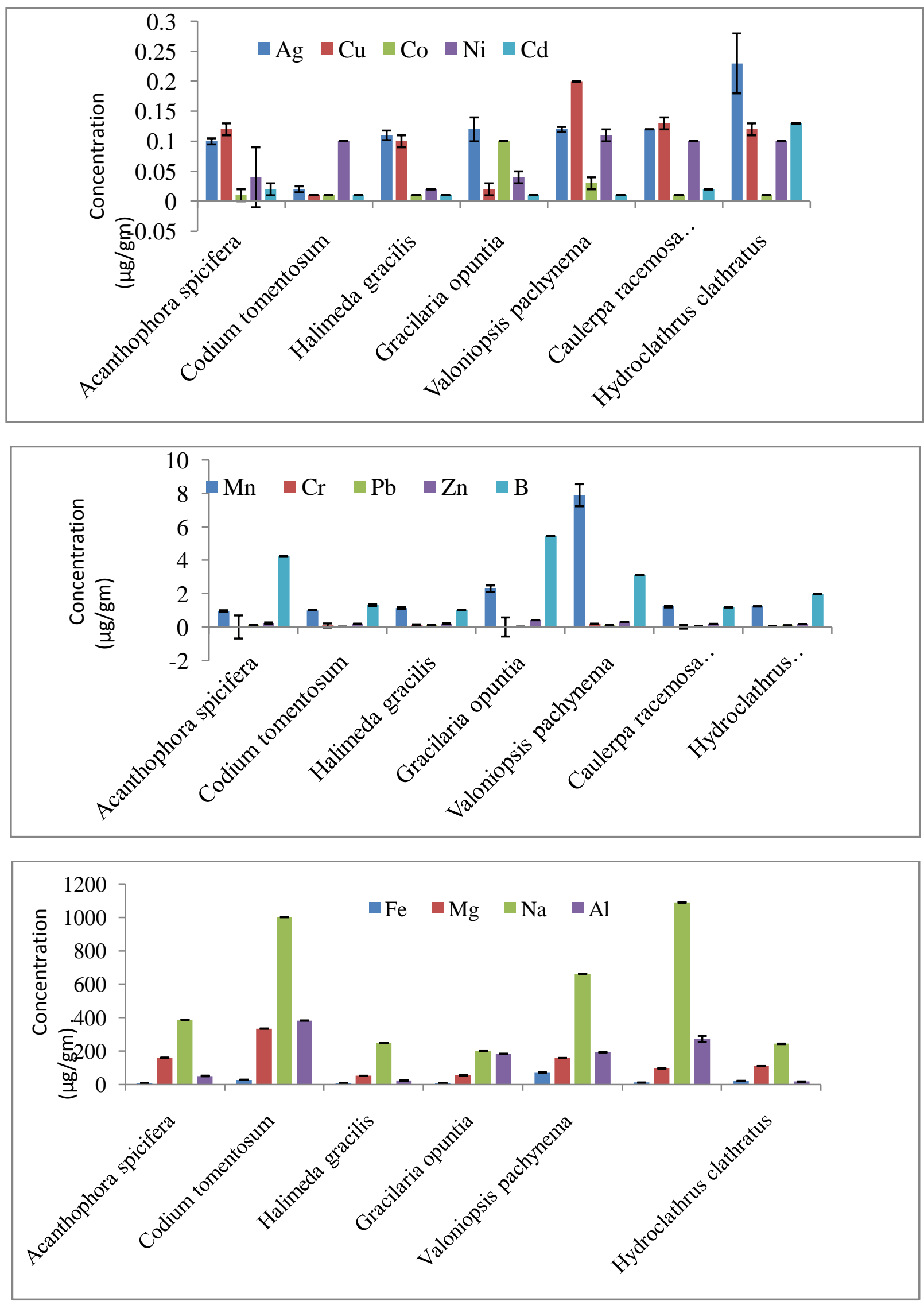
UGC Approved Journal

Graphs represent the result of pre-treatment -II.
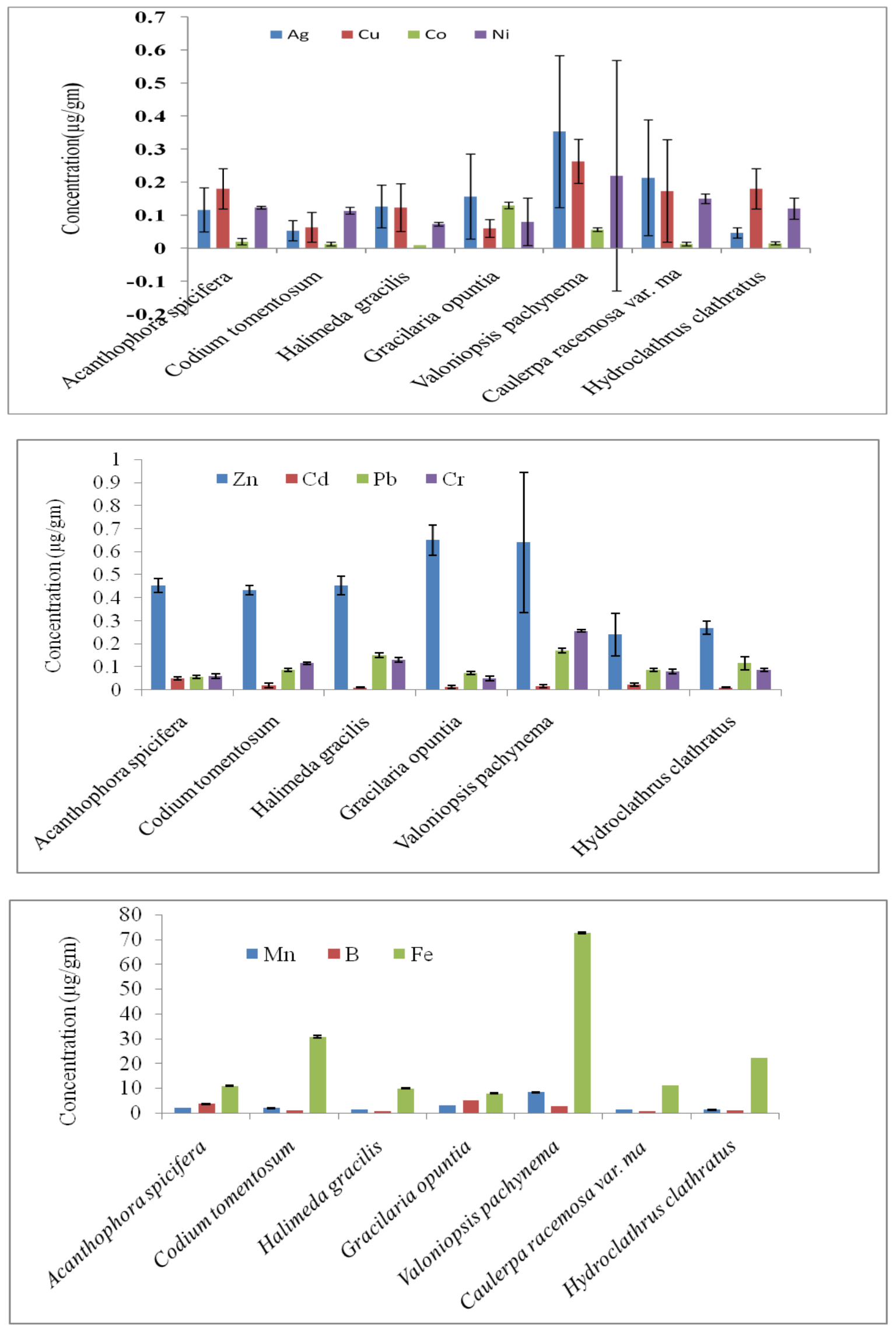


\section{UGC Approved Journal}

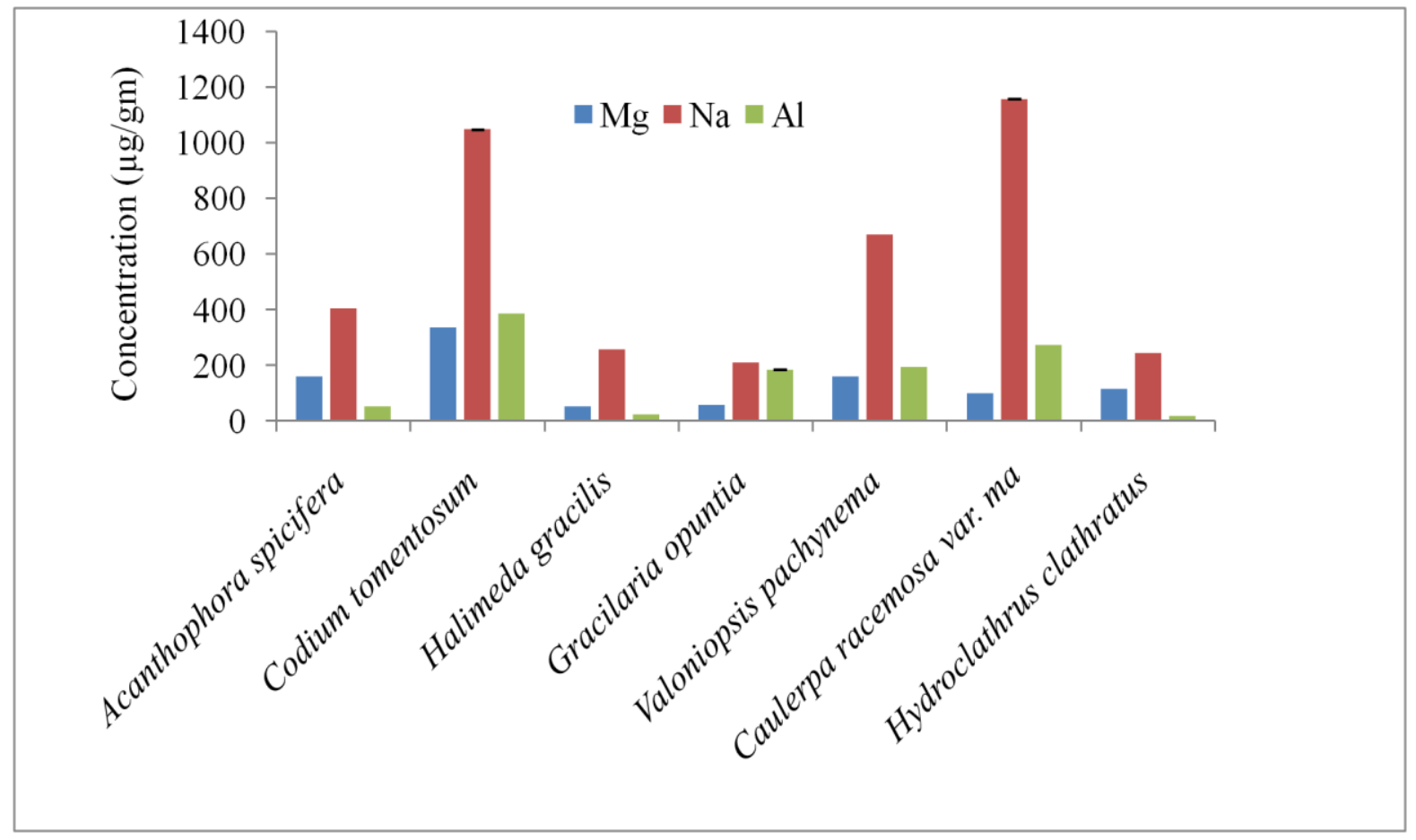

\section{DISCUSSION}

Artificially, anthropogenic activities are including minerals as well as heavy metals in the marine environment but natural inclusion of heavy metals in the marine environment depends on sediment composition, water quality and the route of exposure of heavy metals to the environment. The seaweeds which are growing in highly polluted environment may accumulate high amount of toxic heavy metal (Koch et al. 2007).

There are several possible reasons for variation of metal accumulation. It may be due to seaweeds external and internal morphology, variation in morphology, duration of the life cycle, growth rate, cell wall composition, surface area; environmental contamination; territorial discharges, and water contamination, so those seaweeds having a larger surface area, may accumulate greater amounts of heavy metals; perennial species may accumulate more metals than annual species; fast growing species with less life spend may content less metals. It may also depend on the metal binding affinity of the species which show internal competition of metal binding (Lobban and Harrison, 1994).

The heavy metals such as $\mathrm{Hg}, \mathrm{As}, \mathrm{Cd}$ and $\mathrm{Pb}$ are potential for health hazard and toxic to environment. Seaweeds have the highest potency as a bio indicator for metal pollution in the marine environment because they have fundamental prerequisites for use as bio indicators such as easy to identify and collection, available in throughout the year in almost all coastal areas. The metals are present in high amount in Valoniopsis pachynema, Codium tomentosum and Gracilaria opuntia, so it will be employed as remediator to remove heavy metals from polluted area. The metals content of Acanthophora spicifera, Halimeda gracilis, Caulerpa racemosa var. macrophysa, and Hydroclathrus clathratus are comparatively less, and so they are safe as edible. Some of Caulerpa species are already edible in different coastal countries.

\section{ACKNOWLEDGEMENT}

Authors are thankful to Dean, Director of CAS in Marine Biology, Annamalai University and the staff members of Centralized laboratory at CAS in Marine Biology for ICP-OES analysis. Authors also acknowledged thanks to higher authorities of Annamalai University.

Conflict of interest: Authors have no conflict of interest to declare.

Funding: This work has been conducted by self-funding. 


\section{UGC Approved Journal}

\section{International Advanced Research Journal in Science, Engineering and Technology}

ISO 3297:2007 Certified

Vol. 4, Issue 6, June 2017

\section{REFERENCES}

[1] Ali, H., Khan, E., Sajad, M. A., (2013). Phycoremediation of heavy metals-Concepts and applications. Chemosphere, Volume 91, Issue 7, 869881 .

[2] Bocanegra, A., Bastida, S., Benedí, J., Ródenas, S., Sánchez-Muniz, F. J., (2009); Characteristics and nutritional and cardiovascular health properties of seaweeds. J. Med. Food. 12: 236-258.

[3] Dawczynski, C., Schubert, R., Jahreis, G., (2007), Amino acids, fatty acids, and dietary fibre in edible seaweed products. Food Chem.; 103: 891-899.

[4] Gochfeld, M., (2003). Cases of mercury exposure, bioavailability and adsorption. Ecotoxicol. Environ. Saf. 56, 174-179.

[5] Gupta, S., Abu-Ghannam, N., (2011); Recent developments in the application of seaweeds or seaweed extracts as a means for enhancing the safety and quality attributes of foods. Innov. Food Sci. Emerg. Technol, 12: 600-609.

[6] Koch, I., McPherson, K., Smith, P., Easton, L., Doe, K. G., Reimer, K. J., (2007); Arsenic bio accessibility and speciation in clams and seaweed from a contaminated marine environment. Marine Pollution Bulletin; 54: 586-594

[7] Lavoie-Michel, L. F., Séverine, F., Claude, C. P., (2009); Cadmium detoxification strategies in two phytoplankton species: metal bin ding by newly synthesized thiolated peptides and metal sequestration in granules. Aquat. Toxicol; 92: 65-75.

[8] Lobban, C. S., Harrison, P. J., Books. Google.com Seaweed ecology and physiology,

[9] Rajfur, M., Kłos, A., Wacławek, M., (2010); Bio-sorption properties of algae Spirogyra sp. and their use for determination of heavy metal ions concentrations in surface water. Bio-electrochemistry; 80: 81-86.

[10] Romarís-Hortas, V., García-Sartal C, Del., Carmen Barciela- Alonso, M., (2011); Bioavailability study using an in-vitro method of iodine and bromine in edible seaweed. Food Chem.; 124: 1747-1752.

[11] Storelli, M. M., Storelli, A., Marcotrigiano, G. O., (2001). Heavy metals in the aquatic environment of the southern Adriatic Sea, Italy. macro algae, sediments and benthic species. Environment International 7-8, 505-509.

[12] Villares, R., Puente, X., Carballeira, A., (2002); Seasonal variation and background levels of heavy metals in two green seaweeds. Environ. Pollut. 119: 79-90.

[13] Volesky, B., and Schiewer, S., (1999). Bisorption of metals. In encyclopaedia of Bioprocess Technology, eds. M. Flick-inger and S.W Drew, pp. 433-453. Wiley \& Sons, NY.

[14] Wilson, S., (2002). Nutritional value of detritus and algae in blenny territories on the Great Barrier Reef. J. Exp. Mar. Biol. Ecol. 271 , 155-169. 